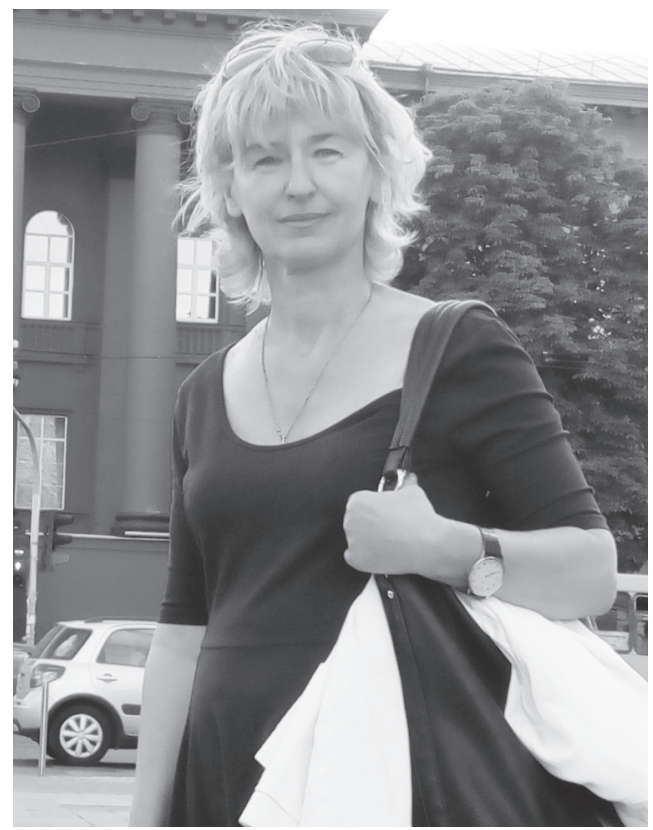

Lapina Viktoria Viktoriona,

culty of Sociology, Taras Shevchenko National University of Kyiv, 01601, Kyiv, Str. Volodymyrska,64/13, tel.: +380506451807, e-mail:v.lapina39@ukr.net

ORCID: 0000-0002-1071-2971

\title{
АРХЕТИП СЕЛЯНИНА: ПРОБЛЕМА НАКОПИЧЕННЯ I ВИКОРИСТАННЯ ЛЮДСЬКОГО КАПІТАЛУ В УКРАÏHI
}

Анотація. Проаналізовано існуючі теоретичні підходи до визначення атрибутативних рис архетипу селянина та ідентифікації підходів змісту соціальних чинників, які зумовлюють потреби в соціальному відтворенні даних рис як стимулів збереження, накопичення та використання людського капіталу. Приділено увагу дискусійному характеру проблеми визначення соціального статусу місця та соціальної ролі селянина в системі сучасних суспільних відносин та комунікацій. Аргументовано, що політичні та економічні трансформації XX-XXI ст. спричинили кардинальні соціально-економічні зміни в сільському господарстві та повністю змінили сам спосіб життя селянина, що необхідно враховувати при здійсненні наукових оцінок перспектив розвитку потенціалу людських ресурсів у сільських громадах. Констатовано, що в умовах сьогодення ще не існує спеціальної соціологічної теорії сільського 
господарства, яка б відповідала сучасним викликам нових форм господарювання, змінам територіального устрою та новітнім глобальним викликам. Тому проблема формування та використання людського капіталу в Україні потребує інноваційного наукового осмислення в аспекті обгрунтування доцільності розвитку нових форм господарювання на селі з обов'язковим урахуванням набутого прогресивного соціокультурного досвіду. Наголошено на важливості концептуальної реконструкції ідей К. Юнга, який запропонував певне визначення атрибутивних рис архетипу селянина. Також з'ясовано систему чинників, які зумовлюють процес стабільного відтворення атрибутативних рис архетипу селянина та монофункціональний характер селянської праці. Надано докази, що такі риси архетипу селянина, як здатність до самодіяльної активності, розрахунку та віри в кінцеву ефективність власної праці, режим самозабезпечення та неформальне піклування не лише про добробут членів свого родинного кола, а й про долю інших людей у кризові часи війн та катастроф - є важливими соціальними чинниками збереження, накопичення та використання людського капіталу в Україні.

Ключові слова: селянин як соціальний суб’єкт, архетип селянина, атрибутивні риси архетипу селянина, сільськогосподарська праця, людський капітал, глобалізація.

\section{АРХЕТИП КРЕСТЬЯНИНА: ПРОБЛЕМА НАКОПЛЕНИЯ И ИСПОЛЬЗОВАНИЯ ЧЕЛОВЕЧЕСКОГО КАПИТАЛА В УКРАИНЕ}

Аннотация. Проанализированы существующие теоретические подходы к определению атрибутативных характеристик архетипа крестьянина и идентификации подходов содержания социальных факторов, обуславливающих потребности в социальном воспроизводстве данных характеристик как стимулов сохранения, накопления и использования человеческого капитала. Обращено внимание на дискуссионный характер проблемы определения социального статуса места и социальной роли крестьянина в системе современных общественных отношений и коммуникаций. Аргументировано, что политические и экономические трансформации XX-XXI в. вызвали кардинальные социально-экономические изменения в сельском хозяйстве и полностью изменили сам образ жизни крестьянина, что необходимо учитывать при осуществлении научных оценок, перспектив развития потенциала человеческих ресурсов в сельских общинах. Констатировано, что в настоящее время еще не существует специальной социологической теории сельского хозяйства, соответствующей современным вызовам новым формам хозяйствования, изменениям территориального устройства и новейшим глобальным вызовам. Поэтому проблема формирования и использования человеческого капитала в Украине требует инновационного научного осмысления в аспекте целесообразности развития новых форм хозяйствования на селе с обязательным учетом накопленного прогрессивного социокультурного опыта. Подчеркнута важность концептуальной реконструкции идей К. Юн- 
га, который предложил характеристку атрибутивных черт архетипа крестьянина. Также выяснена система факторов, которые обусловливают процессы стабильного воспроизводства атрибутивных черт архетипа крестьянина и монофункциональный характер крестьянского труда. Предоставлены доказательства, что такие черты архетипа крестьянина, как способность к самодеятельной активности, расчетливость и вера в конечную эффективность собственного труда, режим самообеспечения и неформальная забота не только о благополучии членов своего семейного круга, но и о судьбе других людей в кризисные времена войн и катастроф - являются важными социальными факторами сохранения, накопления и использования человеческого капитала в Украине.

Ключевые слова: крестьянин как социальный субъект, архетип крестьянина, атрибутативные черты архетипа крестьянина, сельскохозяйственный труд, человеческий капитал, глобализация.

\section{ARCHETYPE OF THE PEASANT: THE PROBLEM OF ACCUMULATION AND PRACTICAL USE OF THE HUMAN CAPITAL OF UKRAINE}

Abstract. The analyzis of the existing theoretical approaches to the research of the attribuive features of the peasant archetype which determinate the social factors that cause the need to study the social reproduction of these features as the stimulus for the preservation, accumulation and use of human capital is prsented in the article. The author pays attention upon the disputable character of the problem that is connected with the identification the social status, the place and the social role of a peasant in the system of the contemporaty social relations and communications. It is argued that the political and economic transformation by the XX-XXI centuries have been caused the radical socio-economic changes in the rural culture and changed the peasant's traditional way of life. Underlined that these circumstances one must have to take into account trying to obtain the relevant scientific evaluations of the prospects for the further development of the human resources in the rural communities. It was emphsized that at present time there is no exists the special sociological theory of rural culture, which corresponds to the global challenges of the new forms of management, and of the innovative changes in the territorial structures of the contemporary societies Therefore, the problem of the formation and the use of human capital in Ukraine requires innovative scientific understanding in the aspect of justifying the need in developing the new forms of business in the rural regions with the obligatory account of the progressive sociocultural experience. The importance of the conceptual reconstruction of the ideas by C. Jung, who in his studies proposed the definition of the attributive features of the peasant archetype was argued. The system of the social factors that determine the process of the sustainable reproduction of these attribute features of the peasant archetype especially in the mono-functional nature of the peasant's labor is investigated by the author. Proved that such features of the peasant archetype as the ability for self-activity, 
calculation and belief in the ultimate efficiendy of own work, self-suppoting and informal care not only about the welfare of members of the family circle, but also about the security of other people in crisis time during the wars and catastrophes are the important social factors for the preservation, accumulation and the rational use of the human capital in Ukraine.

Keywords: peasant as a social actor, peasant archetype, attributive features of peasant archetype, agricultural labor, human capital, globalization, Ukrainian society.

Постановка проблеми. Відомо, що серед актуальних питань, на дослідження яких спрямовані зусилля вчених-суспільствознавців, є питання визначення ролі і місця поняття архетипу селянина у збереженні та використанні людського капіталу на селі та пов'язаних з цим проблем наукового вивчення причин соціального занепаду українського села. Зазначимо, що на сучасному етапі трансформації українського суспільства в аспектах зміни економічних взаємодій, аграрної реформи та створення нових територіальних громад особливої актуальності набула проблема збереження інтересів як громади загалом, так і кожного їі члена. Також зазначимо, що питання накопичення і збереження людського капіталу відіграє все більш важливу роль у формуванні стратегії сталого розвитку суспільства, а саме збереження та розвитку людських ресурсів та їх культурної ідентичності. На шляху до глобальної інтеграції важливо отримати підгрунття соціального прогресу, демократизації та гуманізації суспільства, зокрема в сільських регіонах. Це стосується вирішення таких проблем соціального розвитку, як рівень економіки та добробуту населення, природний, науково-тех- нічний, аграрно-промисловий потенціал, кваліфікаційно-освітній рівень населення, збереження соціально-історичних та культурних традицій народу України, що стає предметом наукових дискусій як в Україні, так і за їі межами.

Саме тому, ми вважаємо, у сучасній теоретичній соціології актуальною науковою проблемою є здійснення аналізу існуючих теоретичних підходів до визначення атрибутивних рис архетипу селянина та ідентифікації підходів змісту соціальних чинників, які впливають на збереження та розвиток людського капіталу, а також зумовлюють потреби в соціальному відтворенні даних рис при розробці ефективних управлінських технологій гуманізації суспільного життя.

Аналіз останніх досліджень і публікацій. Дослідженню проблем села багато уваги приділяли вітчизняні вчені. Так, В. І. Тарасенко [1] вперше звернувся до проблеми наукового вивчення глибинних причин соціального занепаду українського села. Варто нагадати, що у своїх виступах він аргументовано доводив помилковість прийнятого у владних інституціях дихотомічного поділу сільських поселень на “перспективні - непер- 
спективні". Також сільська соціологічна проблематика щодо українського села в умовах трансформаційних перетворень знайшла відображення в результатах наукових досліджень сучасних соціологів - А. Шатохіна, М. Сакади, В. Чигрина та інших українських дослідників проблем села, які головну увагу звертали на ситуацію в аграрному секторі економіки й стан сільського соціуму після зміни політичного та економічного устрою в Україні [2-4].

Варто зазначити, що переважна більшість досліджень останнього часу базується на традиції теоретичного вивчення проблем сільського населення у світовій науці, яка бере початок з XIX ст. (А. Гелен, П. Сорокін, К. Циммерман). Перші спроби осмислення проблем використання людського потенціалу сільського населення у світовий науковій думці започатковані в історії, економіці, пізніше в політекономії, соціології та соціальній психології. В Європі, здебільш на сході та півдні, де в ті часи найбільш розвинено було сільське господарство, перші спроби наукового осмислення проблем селянства з'явилися на початку XX ст. Найбільш прогресивними стали ідеї Ф. Знанецького, якого цілком можна вважати основоположником західної аграрної соціології. Ф. Знанецький перший ініціював проведення соціологічних досліджень 3 вивчення проблем селянства, а саме - відмінності в культурі та традиціях [5]. Результати теоретичних та емпіричних досліджень проблем селянства знайшли відображення у працях класиків соціології кінця XIX - початку XX ст. - П. Сорокіна,
О. Чаянова, В. Большакова. Суттєво вплинули на процеси формування спеціалізованого напряму вивчення сільського життя праці Т. Шаніна, Р. Редфілда, П. Стирлінга, Р. Дюмона, Б. Галенські, К. Добровольського, Дж. Скотта та ін.

Аналіз цих наукових джерел є вагомою підставою для розвитку перспективних досліджень архетипу селянина в аспекті з'ясування можливостей та перспектив сільськогосподарської праці у процесах накопичення та використання людського капіталу в Україні.

3 огляду на зміст наукової проблеми дослідження, метою даної статті є здійснення аналізу існуючих теоретичних підходів до визначення атрибутивних рис архетипу селянина та ідентифікації підходів змісту соціальних чинників, які зумовлюють потреби в соціальному відтворенні даних рис як стимулів збереження, накопичення та використання людського капіталу.

Виклад основного матеріалу. Насамперед варто прийняти до уваги, що у сучасному суспільстві визначення ролі селянина є досить неоднозначною. Селянство традиційно розуміється як “специфічна складова зайнятого в сільському господарстві населення, основним джерелом існування якого є організована в одноосібно-сімейній або кооперативно-колективній формах аграрна праця, що обумовлює системність соціальних зв'язків та характер способу життя, просторово-територіальну локалізацію, а також соціальні відносини, що складаються при цьому, органічність єдності в його життєдіяльності природно-біосферних умов, 
змістом і характером організації виробничих відносин” [6, с. 509].

На мій погляд, таке традиційне тлумачення селянства не повною мірою розкриває зміст того наукового факту, що поняття “селянин” відображує складну та історично-змінну форму соціального самовизначення сільського трудівника.

Тому важливо взяти до уваги точку зору Л. Когана, який зазначає: "Соціологу важливо врахувати принципову відмінність понять “сільське населення” і “селянин”, які часто змішуються і в сучасних дослідженнях. На селі (особливо в сучасний період) живе велика кількість людей, безпосередньо не зайнятих сільськогосподарською працею, яка при будь-якому рівні їі механізації ніколи не стане “різновидом промислової праці". Певна частина сільського населення традиційно зайнята роботою на підприємствах переробної сільськогосподарської продукції в промисловості, будівництві, на транспорті і підприємствах зв'язку, в сфері культури і управління. Тому не можна відносити до сільських мешканців тих городян, що мають свої оселі в селі. Нарешті, в приміських селах проживає велика кількість людей, які працюють на підприємствах сусідніх міст. Говорячи про сільську культуру, ми маємо на увазі саме культуру селянства - основної маси сільського населення. При цьому в поняття “селянин” ми включаємо всіх людей, професійно зайнятих сільськогосподарською працею, незалежно від форм власності та організації їх праці” [7, с. 42-44]. Я вважаю, що це пояснення виокремлює статус селянина від статусу людини, що лише опосередковано має відношення до селянського способу життя, організації соціально-культурних відносин в окремих соціальних групах на визначеній території у конкретний період часу.

Політичні та економічні трансформації XX-XXI ст. спричинили кардинальні соціально-економічні зміни в сільському господарстві та повністю змінили сам спосіб життя селянина. Так, процеси колективізації, кооперації, розвитку фермерських господарств суттєво змінили масові уявлення про образ селянина як хазяїна землі, як активного соціального суб'єкта, який здійснює сільськогосподарську діяльність. У цьому зв'язку слушно виникає питання: чи взагалі залишилася основа селянського буття, що залишилося від традиційної селянської культури, чи є можливість збереження етнокультурної самобутності архетипу українського селянина.

Відповідь на це питання можна знайти у довідковій літературі енциклопедичного характеру. Тому доцільно навести таке положення: "Видозмінюючи свою соціально-економічну форму, селянство проходить через усі формації та епохи людського існування, при цьому зберігає властивий йому соціокультурний архетип, своє призначення сімейного або колективно-громадського господарювання. Індустріалізацію і тим більше автоматизацію аграрного виробництва селянське господарство аж ніяк не відкидає, а використовує найбільш раціонально, в прийнятних йому власними масштабами розміpax" [6, с. 509]. Проте, як здається, проблема потребує більш детально- 
го дослідження та пояснення з позиції осмислення перспектив розвитку потенціалу людських ресурсів в сільських громадах.

Доречно зауважити, що на цей час ще не існує спеціальної соціологічної теорії сільського господарства, яка б відповідала сучасним викликам нових форм господарювання, змінам територіального устрою та новітнім глобальним викликам. Вочевидь, що проблема формування та використання людського капіталу в Україні потребує інноваційного наукового осмислення в аспекті обгрунтування доцільності розвитку нових форм господарювання на селі з обов'язковим врахуванням набутого прогресивного соціокультурного досвіду.

Саме тому, слід звернути увагу на складні форми прямої та опосередкованої залежності наявного стану економічних відносин на селі до певних архетипних осередків традиційного способу життя селян, що формувався протягом багатьох століть. На відміну від міського ринку, який є більш технологічно-розвиненим, інноваційним та динамічним, сільський ринок відрізняється своєю консервативністю. Такі відмінності цілком можна пояснити контрастами сільського та міського менталітету, а також звичаєвим правилам відтворення певного способу життя. Відмінність сільського менталітету визначається схильністю до народних традицій, посиленої релігійності, шанобливим ставленням до культурної спадщини, що передається 3 покоління в покоління. Як зазначає Е. Гіденс, “традиційним культурам властиве шанування минулого, i символи цінуються тому, що міс- тять і увічнюють досвід поколінь” [8, c. 101-102].

Суттєва різниця спостерігається в споживчій поведінці селянина та міського мешканця. Для городян здебільш сприйнятливою $є$ споживча поведінка як члена “суспільства споживання”. Саме такий поведінковий стереотип виникає внаслідок економічної та культурної глобалізації, а також утвердження нових моделей споживання, зокрема, символічного споживання. Споживчі переваги сільських жителів, як відомо, є більш близькими до усталених споживчих традицій і є більш аскетичними.

Варто зазначити, протягом останніх трьох десятиріч в українському суспільстві сформувались нові соціально-економічні категоріі населення, які суттєво відрізняються рівнями доходів та накопиченого багатства, що позначає істотний розрив між багатими та бідними групами людей. Ще одна проблема, яка останні роки постала досить гострою - це відсутність робітників на селі. Цілком певні труднощі конструктивного вирішення цієї проблем гальмують процеси становлення і розвитку індивідуальних господарств та фермерства в Україні. Водночас, значно поширились масові уявлення щодо престижності професій та соціального статусу міського громадянина, що вплинуло на відтік молоді з села в місто, та призвело до зниження трудового потенціалу села.

Тут доречно згадати, що в 5060 роки XX ст. ідеологічна політика передбачала активну пропаганду соціального престижу селянина, що відображувалося в популярних кінофільмах, піснях та художній літе- 
ратурі. У великій пошані був статус колгоспниці як довершеного архетипу сільської жінки, яка працює на ланах, фермі, на посаді керівника колгоспу, та являє собою господиню не лише власної оселі, а є гідним співвласником колективних господарств та шанованим суб'єктом з боку держави. Прикро визнавати, що зараз соціальний статус селянина (селянки) прийняв нову негативну форму - нерозвиненого, недоосвідченого, обділеного інформацією індивіда, і саме тому слово “село” навіть стало використовуватися як образа для людини.

Вочевидь, що цілком реально існують певні соціальні підстави для поширення у суспільстві негативного соціального образу селянина. Приймаючи до уваги цю обставину, доцільно визнати, що здійснення наукової ідентифікації змісту даних підстав має важливу не лише теоретичну, а й практичну значущість. Насамперед важливо звернути увагу на відмінності інтегративних засад міської та сільської культури, які суттєво впливають на усталене відтворення певних способів життя людей. У цьому зв'язку доцільно визнати, що ресурсна база міської та сільської культури загалом обумовлена різними можливостями соціальної інтеграції великих груп населення. Самому характеру праці у місті і селі притаманні різні можливості розподілу системи трудових функцій. Вочевидь, що архетип селянської праці характеризується певною монофункціональністю. Саме цю обставину, як здається, вважав доцільним враховувати К. Юнг, який намагався здійснити ідентифікацію атрибутивних рис $a p$ - хетипу селянина, наголошуючи на фіксації таких властивостей даного архетипу, як: надійність, передбачуваність, послідовність, працездатність, витривалість та терплячість. Слід вважати, що дані риси архетипу селянина визначені К. Юнгом у суто маскулинній проекції. Тому певним доповненням до цих рис можуть бути також і певні характеристики архетипу жінки як матері-трудівниці [9, c. 235-246].

Важливо підкреслити, що на процес стабільного відтворення атрибутивних рис архетипу селянина та монофункціональний характер селянської праці суттєво впливають такі чинники, як: 1) сезонний характер праці; 2) структурні особливості праці, що зумовлено процессами специфічного характеру розподілу часу протягом доби (наприклад, догляд за худобою, який вимушено здійснюється вранці, в обід та ввечері); 3) неможливість додаткових компенсацій за працю у вихідні дні та під час свят; 4) збереження патріархального устрою сім'ї, у якій співіснують представники кількох поколінь, внаслідок чого важливим є піклування та догляд за людьми похилого віку; 5) консерватизм соціалізаційних практик, який базуються на досвіді старших поколінь, що пов'язано зі слабким розвитком мережі дошкільних закладів освіти та виховання; 6) демонстративний характер відкритості до спілкування як чинник, що приховує реальні конкурентні взаємодії між селянами, які виникають внаслідок однотипного та монофункціонального характеру їх праці.

Приймаючи до уваги зміст зазначених чинників, слід вказати на 
вагому значущість соціологічних досліджень, проведених групою українських соціологів під керівництвом В. Тарасенка. Результати цих досліджень переконливо засвідчили про важливість розвитку земельних відносин та особливостей праці селян на землі в умовах сучасних ринкових реформ. Ці дослідження дали змогу повною мірою виявити складні драматургічні реалії сільського життя, які загалом обумовлені монофункціональним характером сільської праці та ㄲï слабким ресурсним забезпеченням як з боку власних коштів селян, так і з боку державних та недержавних комерційних інститутів. Тому і зараз не втрачає своєї наукової актуальності такий висновок: “Загальна картина подій як в системі земельних відносин, так і в сфері політичної боротьби навколо них вельми суперечлива. 3 одного боку, набирає обертів чорний ринок землі, що функціонує на грунті певних “нестиковок”, а загалом недосконалості земельного законодавства, корупції держчиновників та чиновників місцевої влади, юридичної “темноти” селян, проникливості ділків. Цей ринок засвідчує, що сьогодні основним прицілом тіньових покупців є насамперед земельні паї тих селян, котрі не мають змоги їх обробляти. До таємного продажу своєї землі штовхає цих власників безперспективність володіння паями, нужденність, неймовірний стрибок цін на землю, особливо поблизу міст, здоровий глузд: навіщо така земля, яка не дає очікуваного доходу, а податок за неї плати" [1, с. 137].

Слід підкреслити, що саме стихійний характер ринкових трансформа- цій В. Тарасенко вважав найбільш суттєвим чинником дегуманізації суспільного життя в Україні. Особливо актуальною темою його досліджень було наукове вивчення глибинних причин соціального занепаду українського села. Варто нагадати, що у своїх виступах він аргументовано доводив помилковість прийнятого у владних інституціях дихотомічного поділу сільських поселень на “перспективні - неперспективні”. Як вчений-соціолог він аналізував різні ситуації, що призводили до зникнення більше ніж 500 сіл на мапі України i тому він болісно переживав суперечливі реалії “дикого капіталізму” на селі.

Саме тому слід визнати справедливий характер наукової аргументаціï, згідно з якою, отримавши землю, селяни не стали реальними власниками, бо не мали змоги самостійно $\dddot{11}$ обробляти і користуватися плодами своєї праці на ній. 3 самого початку держава не створила для них іпотечного банку, який надавав би селянам кредити хоча б на стартове облаштування господарств. Тому селянство змушене було здавати свої паї в оренду. Орендатор виявив себе тим господарем, який реально володіє чужими гектарами землі, перетворивши орендодавця на “паперового” власника. Він може цього так званого власника навіть не взяти на роботу в своє господарство[1, с. 131-148].

Таким чином, приймаючи до уваги зазначені результати доцільно зробити висновок, що традиційне збереження монофункціонального характеру праці на селі є вагомим чинником подальшої невизначеності тенденцій розвитку соціальної 
інфраструктури, застарілість та недорозвиненість якої є чи не найважливішим стримуючим фактором розвитку людського капіталу. До сказаного додамо, що на офіційному сайті Міністерства аграрної політики та продовольства України розміщені шокуючі статистичні дані щодо інфраструктурного занепаду українських сільських поселень. "Сьогодні у понад половини загальної кількості сіл відсутні фельдшерсько-акушерські пункти, лише третина забезпечена дитсадками, школами - $41 \%$. Дороги з твердим покриттям мають тільки $58 \%$ сіл, дорожнє освітлення $-33 \%$. Це вже не кажучи про те, що обладнання газом становить 84 \%. Мешканці багатьох сіл не мають гарантованих джерел якісного водопостачання, зростає кількість неорганізованих звалищ побутових та промислових відходів. Невирішеність житлових проблем - одна 3 причин відтоку з села молодих фахівців, більшість сільських жителів не в змозі придбати собі житло. Ніхто не буде їхати працювати у сільську місцевість, якщо там немає житла, медичного обслуговування, освіти та інфраструктури. I всі цифри говорять про те, що у цьому напрямі треба багато ще чого зробити" [10].

Аналізуючи наведені цифрові дані, цілком закономірно виникає питання, чи здатне взагалі українське село бути надією, ресурсною основою збереження та подальшого накопичення людського капіталу. Варто вказати, що на даний час у сучасному соціогуманітарному знанні ведуться інтенсивні дискусії стосовно ідентифікації сутнісних характеристик, структурних особливостей та функ- ціональної специфіки людського капіталу. Приймаючи до уваги цю обставину, вважаємо, що необхідно підтримати думку тих дослідників, які підкреслюють, що людський капітал - це здатність людей приймати участь у системі ефективних виробничих взаємодій та комунікацій, а також їх здатність до навчання 3 метою отримання якісної освіти та оволодіння знаннями, які слугують базою активного способу життя на засадах самозайнятості та самозабезпечення й участі в різноманітних практиках громадянського суспільства $[11$, с. $309-312 ; 12$, с. 9-49; 13, c. 249-284; 14, c. 52-69].

3 погляду на зазначені нами атрибутивні риси архетипу селянина важливо врахувати і такі властивості даного архетипу, як здатність до самодіяльної активності, розрахунку та віру на кінцеву ефективність власної праці, режиму самозабезпечення та неформальне піклування не лише про добробут членів свого родинного кола, а й про долю інших людей у кризові часи війн та катастроф. Практична актуалізація саме таких якостей 3 врахуванням новітніх тенденцій економічної, політичної та культурної глобалізації є однією 3 визначальних перспективних тенденцій розвитку сучасної цивілізації.

\section{Висновки і перспективи подаль-} ших досліджень:

1. Аналіз існуючих теоретичних підходів до визначення соціального статусу місця та соціальної ролі селянина в системі сучасних суспільних відносин та комунікацій, дав змогу з'ясувати, що традиційне тлумачення селянства не повною мірою розкриває зміст того наукового факту, 
що поняття “селянин” відображує складну та історично-змінну форму соціального самовизначення сільського трудівника. Саме тому важливим є здійснення ідентифікації дослідницької специфіки наукових підходів до визначення атрибутативних рис архетипу селянина та процесу відтворення даних рис як стимулів збереження, накопичення та використання людського капіталу.

2. Політичні та економічні трансформації XX-XXI ст. суттево змінили традиційну основу селянського буття, селянської культури, але проходячи через усі етапи соціально-економічного розвитку, селянство зберігає властивий йому соціокультурний архетип, своє практичне призначення сімейного або колективно-громадського господарювання. Важливо підкреслити, що цю примітну обставину необхідно враховувати при здійсненні наукових оцінок перспектив розвитку потенціалу людських ресурсів у сільських громадах.

3. Характеру праці у місті і селі притаманні різні можливості в системі розподілу трудових функцій, що значною мірою впливає на інтеграцію сільських груп населення у міське середовище, внаслідок чого особливої актуальності набуває конструктивне вирішення проблеми збереження людського капіталу на селі. Така проблема потребує інноваційного наукового осмислення в аспекті обгрунтування доцільності розвитку нових форм господарювання на селі з обов'язковим врахуванням набутого прогресивного соціокультурного досвіду.

4. Надані докази, що процес стабільного відтворення атрибутивних рис архетипу селянина та монофункціональний характер селянської праці суттево впливають такі чинники, як: 1) сезонний характер праці; 2) структурні особливості праці; 3) неможливість додаткових компенсацій за працю у вихідні дні та під час свят; 4) збереження патріархального устрою сім’ї; 5) консерватизм соціалізаційних практик; 6) демонстративний характер відкритості до спілкування як чинник, що приховує реальні конкурентні взаємодії між селянами, які виникають внаслідок однотипного та монофункціонального характеру їх праці.

5. Осмислюючи перспективи подальшої розробки цієї проблематики, вважається необхідним продовження наукового пошуку в прикладному аспекті гуманітарного знання та врахування проведених теоретичных досліджень для подолання дисбалансів, які існують в економічній, соціальній сферах селянського життя щодо формування сприятливих перспектив розвитку села та розробці системи ефективних соціальних технологій для перспективи створення глобального демократичного суспільства в Україні.

\section{СПИСОК ВИКОРИСТАНИХ ДЖЕРЕЛ}

1. Тарасенко В., Сакада М. Проблема земельного ринку в Україні / Валентин Тарасенко, Микола Сакада // Українське суспільство. 1992-2008. Соц. моніторинг / за ред. В. Ворони, М. Шульги. - К.: Ін-т соціології НАН України, 2008. - С. 131-148.

2. Соціальний розвиток сільських регіонів [Текст] : колективна монографія: матеріали учасників Міжнар. 
інтердисциплінарної конф., присвяченої 165-річчю з часу заснування Уманського держ. аграрного ун-ту та 150 -річчю його перебування в Умані, (21-23 травня 2009 р., Умань) / ред. А. М. Шатохін ; Уманський держ. аграрний ун-т, Уманське товариство істориків-аграрників, Уманське відділення Соціологічної асоціації України, І Історико-архітектурний заповідник "Стара Умань”, ДП “Агро-Ілліч Умань”. - Умань : Сочінський, 2009. - 249 c.

3. Гарбар О. П., Шатохін А. М., Костюк М. В., Ямчук П. М. Українська національно-культурна ідентичність: джерела, сьогодення, погляд у майбутнє [Текст] : матеріали заоч. наук.-практ. конф., 26 листоп. 2015 р. / Уман. нац. ун-т садівництва, каф. соц.-гуманітар. і прав. дисциплін; [О. П. Гарбар та ін. ; редкол.: А. М. Шатохін (голов. ред.), М. В. Костюк, П. М. Ямчук]. Умань: Сочінський, 2015. - 90 с.

4. Соціальний розвиток сільських регіонів [Текст] : колект. монографія / Уман. нац. ун-т садівництва, каф. соц.-гуманітар. і прав. дисциплін. Умань : Сочінський, 2009. - Вип. 3 / [Я. М. Балановський та ін. ; за ред. А. М. Шатохіна, М. В. Костюк]. 2018. - 305 c.

5. Znaniecki F. Badania nad wsia wielkopolska / F. Znaniecki // Przeglad Socjologiczny. - 1936. - T. IV. Z. 3-4. - p. 613-620.

6. Социологическая энциклопедия. T. 1. - М.: Мысль, 2003. - С. 509.

7. Коган Л. Н. Социология культуры: учеб. пособие / Л. Н. Коган. Екатеринбург: УрГУ, 1992. - С. 4244.

8. Гидденс Э. Последствия модернити. Новая постиндустриальная волна на Западе. Антология / Э. Гидденс / под ред. В. Л. Иноземцева. M.: Academia, 1999. - C. 101-122.
9. Bazikyan S. A. Sociocultural Models for Interpretation of C. G. Jung Archetypes in Advertising Industry / Stanislava A. Bazikyan. Sociocultural // Journal of Siberian Federal University. Humanities \& Social Sciences 2 (2013. 6). - p. 235-246.

10. Олена Ковальова. Сільський розвиток можливий через партнерство держави, бізнесу та громад. [Електронний ресурс]. - Режим доступу: http://minagro.gov.ua/uk/ pressroom?nid=24571

11. Добрынин А. Н., Дятлов С. А., Цьренова Д. Е. Человеческий капитал в транзитивной экономике: формирование, оценка, эффективность использования / А. Н. Добрынин, С. А. Дятлов, Д. Е. Цыренова // Междунар. научный журнал "Символ науки”. - 2016. - № 5. - СПб.: Наука. - С. 309-312.

12. Becker $G$. $S$. Investment in Human Capital: A Theoretical Analysis / G. S. Becker // The journal of political economy. - № 5 (70). - 1962. p. 9-49.

13. Anikin V. A. Occupational Propensity for Training in a Late Industrial Society: Evidence from Russia / V. A. Anikin // International Journal of Training and Development. - 2017. - № 4 (21). - p. 249-284.

14. Пикетти T. Капітал у ХХІ столітті / Тома Пікетті / пер. 3 англ. Н. Палій. - К. : Наш формат, 2016. 696 c.

\section{REFERENCES}

1. Tarasenko V., Sakada M. (2008). Problema zemelnoho rynku v Ukraini [The problem of the land market in Ukraine]. Ukrainske suspilstvo. 1992-2008. Sotsiolohichnyi monitorynh - Ukrainian Society. 1992-2008. Sociological monitoring. V. Vorona, M. Shulha (Eds.). (p. 131-148). Kyiv: 
In-t sotsiolohii NAN Ukrainy [in Ukrainian].

2. Shatokhin A. M. (Eds.). (2009). Sotsialnyi rozvytok silskykh rehioniv Social development of rural regions: Proceedings of the international interdisciplinary conference devoted to the $165^{\text {th }}$ anniversary since the founding of the Uman State Agrarian University and $150^{\text {th }}$ anniversary of its stay in Uman. Uman: Sochinskyi [in Ukrainian].

3. Harbar O. P., Shatokhin A. M., Kostiuk M. V., Yamchuk P. M. (2015). Ukrainska natsionalno-kulturna identychnist: dzherela, sohodennia, pohliad u maibutnie - Ukrainian national-cultural identity: source, present, view into the future: Proceedings of correspondence scientific and practical conference. Uman: Sochinskyi [in Ukrainian].

4. Balanozskyi Ya. M., et. al. (2018). Sotsialnyi rozvytok silskykh rehioniv [Social development of rural regions]. A. M. Shatokhin, M. V. Kostiuk (Eds.). Uman : Sochinskyi [in Ukrainian].

5. Znaniecki F. (1936). Badania nad wsia wielkopolska. Przeglad Socjologiczny, IV, 3-4, 613-620 [in Polish].

6. Sotsiologicheskaya entsiklopediya [Sociological encyclopedia]. (2003). Vols. 1. Mysl: Moskva [in Russian].

7. Kogan L. N. (1992). Sotsiologiya kultury [Sociology of Culture]. Ekaterinburg: UrGU [in Russian].

8. Giddens E. (1999). Posledstviya moderniti. Novaya postindustrialnaya volna na Zapade. Antologiya [Consequences of modernity. New post-in- dustrial wave in the West. Anthology]. V. L. Inozemtsev (Eds.). Moscow: Academia [in Russian].

9. Bazikyan S. A. (2013). Sociocultural Models for Interpretation of C.G. Jung Archetypes in Advertising Industry. Journal of Siberian Federal University. Humanities \& Social Sciences, 2, 235-246 [in English].

10. Stryzheus A. (2017). Olena Kovalova: Silskyi rozvytok mozhlyvyi cherez partnertvo derzhavy, biznesu ta hromad [Olena Kovaleva: Rural development is possible through the partnership of the state, business and communities]. minagro.gov.ua. Retrieved from http://minagro.gov.ua/uk/ pressroom?nid=24571 [in Ukrainian].

11. Dobrynin A. N., Dyatlov S. A., Tsyrenova D. E. (2016). Chelovecheskiy kapital v tranzitivnoy ekonomike: formirovanie, otsenka, effektivnost ispolzovaniya [Human capital in a transitive economy: formation, evaluation, efficiency of use]. Simvol nauki - Symbol of Science, 5, 309-312 [in Russian].

12. Becker G. S. (1962). Investment in Human Capital: A Theoretical Analysis. The journal of political economy, 5(70), 9-49 [in English].

13. Anikin V. A. (2017). Occupational Propensity for Training in a Late Industrial Society: Evidence from Russia. International Journal of Training and Development, 4 (21), 249-284 [in English].

14. Piketty T. (2016). Kapital u XXI stolitti [Le Capital au XXI siècle]. (N. Palii, Trans). Kyiv: Nash format [in Ukrainian]. 